\title{
Nickel affects xylem Sap RNase a and converts RNase $A$ to a urease
}

\author{
Cheng Bai ${ }^{1,2^{*}}$, Liping Liu ${ }^{1}$ and Bruce W Wood ${ }^{2}$
}

\begin{abstract}
Background: Nickel (Ni) is an essential micronutrient; however, its metabolic or physiological functions in plants and animals are largely uncharacterized. The ribonucleases (RNase, e.g., RNase A) are a large family of hydrolases found in one form or many forms facilitating nitrogen $(\mathrm{N})$ cycling. It is currently unknown how either a deficiency or excess of $\mathrm{Ni}$ influences the functionality of ribonucleases, like RNase A. This is especially true for perennial crops possessing relatively high Ni requirements.

Results: We report that the 'rising' xylem sap of pecan [Carya illinoinensis (Wangenh.) K. Koch, a long-lived tree] at bud break contains a 14 kDa RNase A (aka, RNase 1), which amount has a 33\% greater in Ni-deficient as in $\mathrm{Ni}$-sufficient trees when exposed to $\mathrm{Ni}$ ions exhibits ureolytic activity. The homologous $13.4 \mathrm{kDa}$ bovine pancreatic RNase A likewise exhibits ureolytic activity upon exposure to Ni ions. Ni therefore affects enzymatic function of a typically non-metalloenzyme, such as it transforms to an enzyme capable of hydrolyzing a linear amide; thus, converting an endonuclease esterase into a urease.

Conclusions: We conclude that Ni potentially affects the level and activity of RNase A present in the spring xylem sap of pecan trees, and probably in other crops, it has the same influence. The catalytic property of RNase A appears to shift from a nuclease to a urease relying on $\mathrm{Ni}$ exposure. This is suggestive that RNase A might possess novel metabolic functionality regarding $\mathrm{N}$-metabolism in perennial plants. The ability of $\mathrm{Ni}$ to convert the activity of plant and animal RNase A from that of a ribonuclease to a urease indicates a possible unrecognized beneficial metabolic function of $\mathrm{Ni}$ in organisms, while also identifying a potential detrimental effect of excessive $\mathrm{Ni}$ on $\mathrm{N}$ related metabolic activity if there is sufficient disruption of $\mathrm{Ni}$ homeostasis.
\end{abstract}

Keywords: Urea, Pecan, Xylem sap, Ribonuclease, Nickel, Nitrogen cycling

\section{Background}

Nickel appears to be essential for life. Lower plants require $\mathrm{Ni}$ as an essential co-factor for many metalloenzymes [1], and higher plants require $\mathrm{Ni}$ as a co-factor for urease (EC 3.5.1.5, urea amidohydrolase) [2-4]. The roles of $\mathrm{Ni}$ in animal metabolism and physiology are largely uncharacterized; although, it appears to be essential, yet specific essential roles continue to evade elucidation [5]. The relatively broad adverse physiological impact of

\footnotetext{
* Correspondence: chengbai2001@163.com

'Laboratory of Pests Comprehensive Governance for Tropical Crops, of Ministry of Agriculture, Hainan Laboratory for Monitoring and Control of Tropical Agricultural Pests, Hainan Engineering Research Center for Biological Control of Tropical Crops Diseases and Insect Pests, Environment and Plant Protection Institute, Chinese Academy of Tropical Agricultural Sciences, Haikou, Hainan 571101, China

${ }^{2}$ United States Department of Agriculture, Agricultural Research Service, Southeast Fruit and Tree Nut Research Laboratory, Byron, GA 31008, USA
}

severe Ni deficiency in both plants and animals hints of multiple essential roles.

Urease is one of the few metalloenzymes known to require $\mathrm{Ni}$ for activity. The essential role for $\mathrm{Ni}$ in plants is partially based on the discovery that highly functional urease typically requires $\mathrm{Ni}$ ions. Urease is ubiquitous in higher plants because of its unique role in $\mathrm{N}$ metabolism for hydrolyzing urea, a linear amide, to $\mathrm{NH}_{4}^{+}$and $\mathrm{CO}_{2}$. Ureases vary in molecular size and number of subunits, depending on biological source. Most forms are relatively large proteins possessing small subunits [e.g., jack bean urease (a $580 \mathrm{kDa}$ hexamer with identical subunits of $90,970 \mathrm{Da}$, and containing two Ni ions per subunit) [6] and urease from Klebsiella aerogenes (a Ni-containing multicomponent urease, $224 \mathrm{kDa}$; subunits of 72, 11 and $9 \mathrm{kDa}$; about two $\mathrm{Ni}$ ions per $72 \mathrm{kDa}$ subunit)] [7]. Nickel is therefore important in 
plant metabolic processes, especially when rapid growth requires relatively large amounts of chemically reduced- $\mathrm{N}$ as $\mathrm{NH}_{4}^{+}$.

The ability of organisms to metabolize and recycle $\mathrm{N}$ is requisite for life. Cycling involves many enzymes, with ribonucleic acid depolymerases (ribonucleases, or RNases), and their homo- and orthologues, playing a major role in breakdown and recycling of $\mathrm{N}$-containing ribonucleic acids (RNAs). Prominent among the RNase forms is RNase A (RNase, EC 3.1.27.5), a highly durable protein ubiquitous in plants and animals [8,9]. RNase A is a non-metalloenzyme that cleaves single-stranded RNA at the 3 '-end of pyrimidine residues and degrades RNA into 3'-phosphorylated mono- and oligo-nucleotides. This relatively small enzyme (13,473 Da for bovine pancreatic RNase $\mathrm{A}$ ) is a monomer that forms a dimer (comprises of both a relatively large and a smaller component) upon concentration in mild acid. RNase is a highly stable enzyme, maintaining enzymatic integrity as an endonuclease esterase under conditions that cause most enzymes to lose functionality. The ribonuclease superfamily consists of many forms, homologues and orthologues, possessing novel biological activity based on ribonuclease homology [10,11]. The RNase A molecule can bind $\mathrm{Ni}$ ions [12,13], but it is unknown whether this affects hydrolase activity and catalyzing function.

Many enzymes exhibit limited dual catalytic activity, catalyzing more than one reaction type. Structural similarities between RNase A and urease molecules indicate that RNase A might be capable of hydrolyzing linear amides, such as urea, if $\mathrm{Ni}$ ions modify its molecular structure. If the $\mathrm{Ni}$ complex exhibits ureolytic activity then it might serve as an alternative means for ensuring timely $\mathrm{N}$-metabolism in organisms [14]. An example might be the mobilization and conversion of organic- $\mathrm{N}$ within xylem sap of perennial plants as they transition from dormancy to active growth when $\mathrm{Ni}$ is in xylem sap.

Xylem sap of perennial plants can contain ribonucleases [15], but it is unknown whether they are present in long-lived perennials, such as pecan [Carya illinoinensis (Wangenh.) K. Koch]. Species possessing relatively high $\mathrm{Ni}$ requirements might benefit from $\mathrm{Ni}$-associated ureolytic activity when reduced- $\mathrm{N}$ is, or is about to be, in high demand due to rapid growth of canopy organs during early spring [16]. It is presently unknown whether RNase A occurs in pecan xylem sap, and if so, whether it possesses ureolytic activity. It is also unknown whether RNase A from animals also exhibits ureolytic activity in presence of $\mathrm{Ni}$. We therefore investigated these possibilities and found that xylem sap of pecan trees at time of spring bud break does indeed contain RNase A, and that exposed to $\mathrm{Ni}$ ions potentially converts pecan RNase A and bovine pancreatic RNase A to a urease.

\section{Results}

Pecan xylem sap at time of bud break contained a $14 \mathrm{kDa}$ protein (Figure 1A). Sodium dodecyl sulfatepolyacrylamide gel electrophoresis (SDS-PAGE) indicated that this protein possesses a molecular mass $\left(M_{r}\right)$ similar to purified $13.4 \mathrm{kDa}$ bovine pancreatic RNase A (Figure 1B; from USIB Corporation, Cleveland, $\mathrm{OH}$, USA). The primary structure of pancreatic RNase A from different sources is known [17]. Purified xylem sap protein exhibits a single protein band of $14 \mathrm{kDa}$ (Figure 1B) and was only about $33 \%$ as abundant in the xylem sap of 'Ni-deficient' as in 'Ni-sufficient' trees (Table 1). Similarly, xylem sap Ni was $48.4 \mu \mathrm{g} / \mathrm{L}$ in 'Nisufficient' trees and $12.8 \mu \mathrm{g} / \mathrm{L}$ in 'Ni-deficient' trees ('Table 1).

The ureolytic activity of freshly purified $14 \mathrm{kDa}$ xylem sap protein exhibits 371 units/mg protein (Table 2) compared to 25 units/mg for the crude xylem protein. The specific activity of the purified $14 \mathrm{kDa}$ protein was 223 units/mg, which compares to 589 units/mg of purified jack bean urease (590 kDa) and purified bovine pancreatic RNase A (13.4 kDa) (Table 2). The $14 \mathrm{kDa}$ xylem sap protein therefore exhibits roughly the same specific activity, as does bovine pancreatic RNase A, and about $40 \%$ that of jack bean ureases (Table 2).

Sequence determination (BLAST Search, NCBI) confirms that the $\mathrm{N}$-terminal amino acid sequence of the $14 \mathrm{kDa}$ pecan xylem sap ureolytic protein (Figure 2) is $96 \%$ identical to that of bovine pancreatic RNase A (RNase 1) and bovine pancreatic chain A 1 (or F46aRNase A, F46vRNase A, and F46lRNase A) [18]. This slight $M_{r}$ difference between these two RNases might be due to a transacted form of certain amino acid residues in the xylem sap protein, or a few amino acid residues longer for the bovine RNase A. This indicates that the $14 \mathrm{kDa}$ ureolytic protein from pecan xylem sap is likely RNase A, and this is further confirmed in that this xylem sap protein also exhibits RNase A activity (Figure 3). Similarly, the purified bovine $13.4 \mathrm{kDa}$ RNase A and pecan RNase A did indeed possessed nuclease activity in that it cleaved RNA (Figure 3). The BLAST (NCBI) database [18] indicates that the amino acid sequence of bovine pancreatic RNase A (total 124 amino acid residues) is $44-100 \%$ matched in seven molecular regions with urease (total 567 amino acid residues; Figure 4) from Psychrobacter cryohalolentis $\mathrm{K} 5$ [8]; however, there is no apparent sequence matching with jack bean urease [18]. The Ni dose used was positively correlated with the ureolytic activity of RNase A from either bovine or pecan xylem sap, with both activated by relatively high concentration of Ni ions (Table 3). Bovine pancreatic RNase A catalyzes the hydrolysis of urea (Figure 5), with 


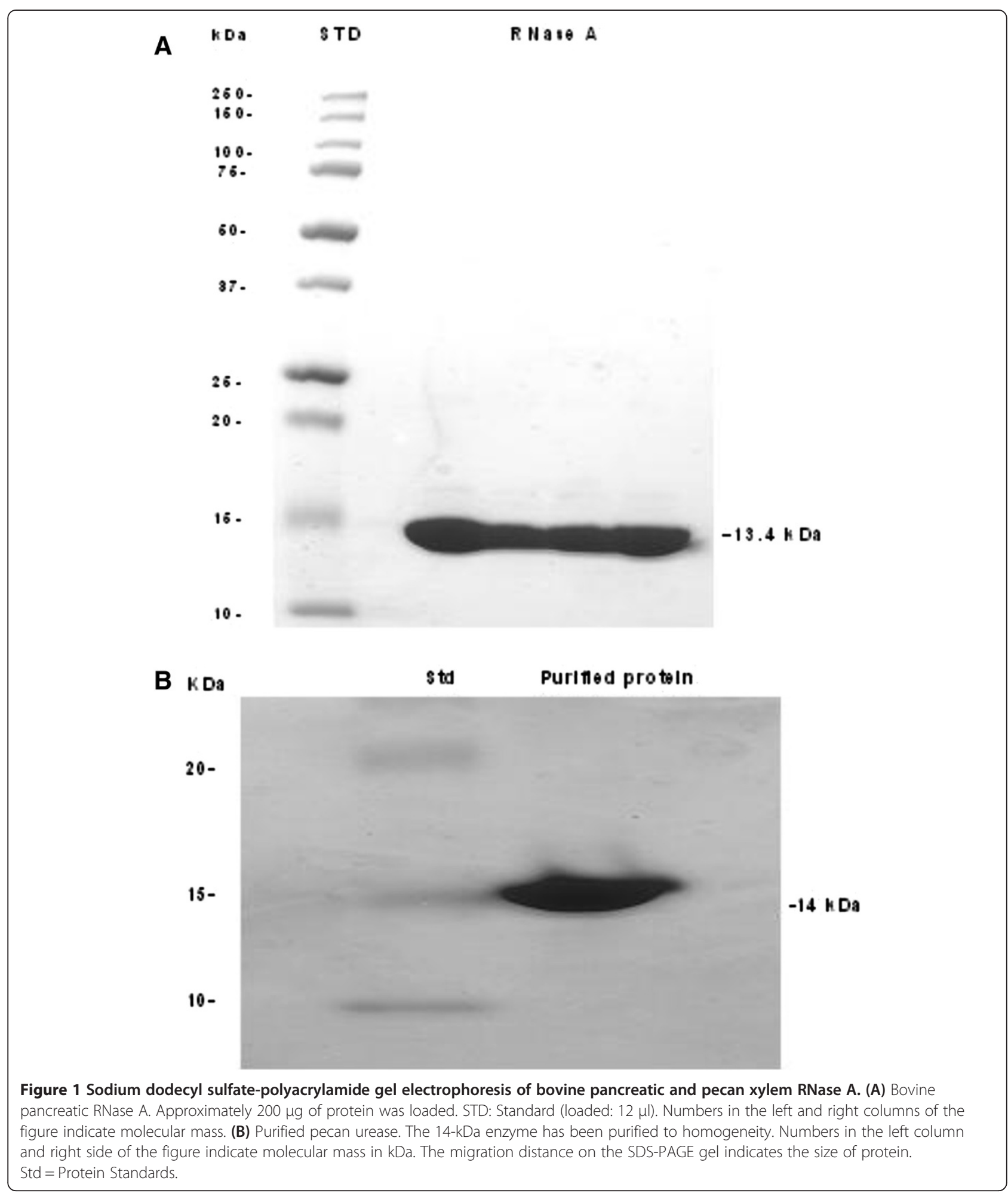

reaction time being a critical factor for hydrolysis-i.e., the longer of the reaction time, the greater the urea hydrolysis. Urea degrading activity increases as amount of RNase A increases in the reaction mixture (Figure 5).

\section{Discussion}

RNase $A$ in pecan xylem sap

Ribonuclease activity, molecular mass and amino acid sequence analysis identified a $14 \mathrm{kDa}$ RNase A present as a component of the late winter xylem sap of a long- 
Table 1 Concentration RNase A in pecan xylem sap as a function of Ni nutritional status

\begin{tabular}{lll}
\hline Tree Ni nutritional status & Xylem sap Ni $(\boldsymbol{\mu g} / \mathbf{L})$ & RNase $\mathbf{A}(\mathbf{m g} / \mathbf{L})$ \\
\hline Ni-sufficient & $48.4 \mathrm{a}^{\mathrm{Z}}$ & $8.4 \mathrm{a}$ \\
$\mathrm{Ni}$-deficient & $12.8 \mathrm{~b}$ & $2.9 \mathrm{~b}$ \\
\hline
\end{tabular}

${ }^{z}$ Means are statistically different by ANOVA at $\mathrm{P}<0.0004$ when followed by different letters.

lived perennial tree crop at a time when the pecan tree is transitioning from dormancy to initiation of early spring growth. This is a time when the tree requires access to considerable amounts of chemically reduced $\mathrm{N}$ for growth of new tissues and organs in preparation for the upcoming growing season. The Ni nutritional status influences the concentration of xylem sap RNase A. A biochemical consequence of $\mathrm{Ni}$ deficiency in plants is a potential reduction in RNase A within spring xylem sap. This deficiency potentially limits $\mathrm{N}$ cycling and metabolism at a critical time, in which perennial plants are preparing for rapid growth, by impairing RNA catabolism in apoplastic space.

\section{Activity of the pecan Ni-RNase A complex}

It is of physiological significance that when pecan RNase $\mathrm{A}$ is exposed to $\mathrm{Ni}$ it exhibits ureolytic activity. The ureolytic activity of this xylem sap $14 \mathrm{kDa}$ Ni-RNase A complex is similar to that of the bovine pancreatic NiRNase A complex, but only about $40 \%$ as great as that of jack bean urease. While there is a theoretically possibility that the purified xylem sap RNase A protein contained a urease contaminate, the rigor of the purification protocol is unlikely to have left such a contaminate. However, further study is required in order to definitively eliminate such a possibility. The results are suggestive that xylem sap RNase A plays a duel role in regards to early season $\mathrm{N}$ metabolism of perennial plants. In addition to a primary function of cleaving

\begin{tabular}{|c|c|c|}
\hline Sample & $\begin{array}{l}\text { Activity } \\
{\text { (Unit/ml })^{a}}^{a}\end{array}$ & $\begin{array}{l}\text { Specific activity } \\
{\text { (Unit/mg protein })^{a}}\end{array}$ \\
\hline $\begin{array}{l}\text { Purified bovine pancreatic } \\
\text { RNase A (13.4 kDa) }\end{array}$ & $179.9 \pm 15.7$ & $179.9 \pm 15.7$ \\
\hline $\begin{array}{l}\text { Purified jack bean urease } \\
(590 \mathrm{kDa})^{\mathrm{b}}\end{array}$ & $589.0 \pm 64.1$ & $589.0 \pm 64.1$ \\
\hline Crude xylem sap proteins & $24.93 \pm 2.04$ & $80.41 \pm 6.56$ \\
\hline $\begin{array}{l}\text { Purified xylem sap } 14 \\
\text { kDa protein }\end{array}$ & $371.25 \pm 17.33$ & $222.75 \pm 10.44$ \\
\hline Buffer control & 0 & 0 \\
\hline
\end{tabular}

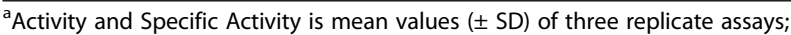
urease catalyzes the hydrolysis of urea to ammonia and carbon dioxide. ${ }^{b}$ The molecular mass for native jack bean urease is from $480 \mathrm{kDa}$ to $590 \mathrm{kDa}^{13}$ and calculated size is about $540 \mathrm{kDa}$ for the hexamer.
RNA, there is a putative secondary function of catabolizing urea in ascending xylem sap and associated apoplastic space. These activities are likely to vary as a function of sap Ni concentration. Whether or not this ureolytic activity actually occurs in planta remains to be determined. The presence of urea in the apoplast, from either urea uptake from soil by roots, or from catabolism of purine nucleotides, ureide pathway intermediates, or from arginine argues that small apoplastic proteins capable of converting urea to $\mathrm{NH}_{4}$ might prove metabolically important, especially during the time of transitioning from dormancy to active growth.

\section{The influence of Ni on RNase A}

Our finding that the Ni-RNase A complex from sources as diverse as pecan and cattle exhibits substantial ureolytic activity naturally raises questions about its relevance to $\mathrm{N}$ metabolism naturally occurring in plants and animals. It appears that the nature of this ureolytic activity depends on cellular Ni status, which in turn should vary according to homeostatic processes and organismal exposure to $\mathrm{Ni}$. Transition metal ions, such as $\mathrm{Ni}$, elicit various enzymatic characteristics, including nucleophilic catalysis, electron transfer, and stabilization of protein structure. X-ray diffraction and three-dimensional structures of RNase A indicates the enzyme possess potential to bind $\mathrm{Ni}$ ions at His 105, where it acts as a nucleation site and causes a conformational change [19] capable of enabling significant ureolytic activity. Similarly, a plant urease from Kiebsilla aerogenes appears to possess a functional requirement for two $\mathrm{Ni}$ ions per active site [7], with Ni ions bound at Arg 70 and Gly 197 (amino acid residues) where $\mathrm{Ni}$ easily makes contact with urea substrate molecules [13].

Observations herein indicate that $\mathrm{Ni}$ binding to RNase A, normally a non-metalloenzyme, enables ureolytic activity; thus, the Ni-RNase A complex is functionally an alternative molecular form of urease, an essential Nimetalloenzyme. This complex might therefore play a role in urea catabolism by perennial plant species, especially those like pecan that possess relatively high $\mathrm{Ni}$ requirements. A similar role might also exist in other plants and animals. While $\mathrm{Ni}$ possesses an essential metabolic role in plants and animals, that role is somewhat enigmatic. It now appears possible that in certain cases Ni could be influencing $\mathrm{N}$ cycling through its influence on RNase A. While many proteins can bind or contain Ni [20], this aspect of Ni nutritional physiology in has received little attention in planta or in animal.

Several enzyme systems in bacteria and lower plants require Ni. Examples include NiFe-hydrogenase, carbon monoxide dehydrogenase, acetyl-CoA decarbonylase synthase, methyl-coenzyme $\mathrm{M}$ reductase, superoxide dismutase, $\mathrm{Ni}$-dependent glyoxylase, aci-reductone dioxygenase, and 


\section{A $14 \mathrm{KDa}$ Pecan sap Urease Bovine Pancreatic RNase A B \\ $14 \mathrm{KDa}$ Pecan SAP Urease Bovine Pancreatic Chain A1 F46aRNase A F46VRNase A F461RNase A \\ 1 KETAAAKFERQHMDSSTSAASSSNYYNQM 29 \\ 5 KETAAAKFERQHMDSSTSAASSSNYCNQM 33 \\ 1 KETAAAKFERQHMDSSTSAASSSNYYNQM 29 \\ 1 KETAAAKFERQHMDSSTSAASSSNY NQM 29 \\ 1 KETAAAKFERQHMDSSTSAASSSNYCNQM 29 \\ 1 KETAAAKFERQHMDSSTSAASSSNYCNQM 29 \\ 1 KETAAAKFERQHMDSSTSAASSSNYCNQM 29}

Figure 2 The $\mathrm{N}$-terminal sequence and alignment of 14-kDa pecan sap RNase A with reported proteins. (A) 14-kDa pecan sap RNase A. The matching of the sequence alignment (within 29 amino acid residues) is 96\%. (B) Bovine pancreatic RNase A. The matching of the sequence alignment (N-terminal first 29 amino acid residues) is $96 \%$.

methyleneurease $[1,21,22]$. It is the activation of urease, to date, that is the most commonly recognized function of $\mathrm{Ni}$ in higher plants [22]. Ni can also replace $\mathrm{Zn}$ or Fe, and other transition metal ions, in certain other metalloenzymes of lower plants [1], and can probably do so to some degree in higher plants and animals. Circumstantial evidence indicates that ureide-transporting plant species, such as pecan, possess a higher $\mathrm{Ni}$ requirement than amide-transporting species [23]; thus, raising the possibility that ureide transporting species might possess enzymes, other than the standard ubiquitous urease, that require $\mathrm{Ni}$ for activation or for enhanced activity. Likely candidates are one or more enzymes affecting $\mathrm{N}$ metabolism; thus, raising the possibility, that RNase A possesses a dual role in cellular metabolism and that this role depends on endogenous bioavailability of $\mathrm{Ni}$.

This potential ureolytic form of RNase A in plants and animals possibly affects $\mathrm{N}$-metabolism via hydrolysis of either urea or RNA depending on $\mathrm{Ni}$ exposure. For example, in germinating rice seeds, $\mathrm{Ni}^{2+}$ exposure increases the levels of RNA by a decline in hydrolysis [24-26]; however, in eggplant ribonuclease activity is increased by $\mathrm{Ni}^{2+}[26]$.

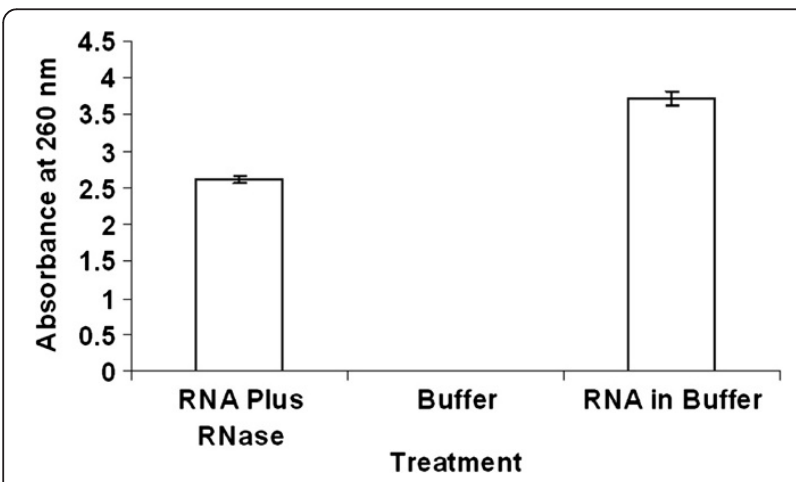

Figure 3 Cleavage of RNA with bovine pancreatic $13.4 \mathrm{kDa}$ protein. Cleaving RNA with the pecan sap $14 \mathrm{kDa}$ RNase A protein produces a similar graph.
This is the first report of RNase A exhibiting urease activity; hence, we postulate that the reaction for urea hydrolysis in many organisms is as follows:

$$
\left(\mathrm{NH}_{2}\right)_{2} \mathrm{CO}+\mathrm{H}_{2} \mathrm{O} \frac{\text { Urease or RNase A }}{\mathrm{Ni}^{++}} \mathrm{CO}_{2}+2 \mathrm{NH}_{3}
$$

It appears that not only does bovine pancreatic RNase A potentially possess duel functionality as urease when exposed to $\mathrm{Ni}$ ions, but that a pecan orthologue also functions as an urease within the early spring xylem sap of pecan when $\mathrm{N}$ reserves are being mobilize from storage tissues to emerging sinks. Urea is a catabolic product of ureide catabolism, e.g., allantoate and ureidoglycolate [27-29]; thus, the xylem sap, and affiliated apoplast, of many long-lived perennials may be a location contributing to the conversion of urea to $\mathrm{NH}_{4}$ in preparation for protein and nucleic acid anabolism because of imminent deployment of canopy organs. Both free and bound $\mathrm{Ni}$ readily transports in xylem vessels [30-32] and therefore potentially influences the nature of RNase A activity.

This discovery potentially broadens knowledge of possible secondary roles of RNase A in organisms in regards to $\mathrm{N}$ metabolism. Because several structural orthologues or paralogues of ribonucleases possess biological action $[10,11]$, it is possible that $\mathrm{Ni}$ binding to these proteins also alters their activity; thus, highlighting new possibilities for metabolically important roles for $\mathrm{Ni}$ in higher organisms.

\section{Methods}

\section{Plant materials}

Three-year-old pecan seedlings, originating from seed of open pollinated 'Desirable' cv. trees, were grown in pots within a greenhouse to produce two Ni nutritional classes of trees-'Ni sufficient' $\left(\mathrm{Ni}^{+}\right)$vs. 'Ni deficient' $\left(\mathrm{Ni}^{-}\right)$, based on expression of morphological symptoms of $\mathrm{Ni}$ deficiency [11]. The $\mathrm{Ni}^{-}$trees were produced from growing in a Tifton Loamy Sand soil. This soil often causes $\mathrm{Ni}$ deficiency symptoms in associated commercial pecan orchards. $\mathrm{Ni}^{+}$trees from the same soil had prior season 


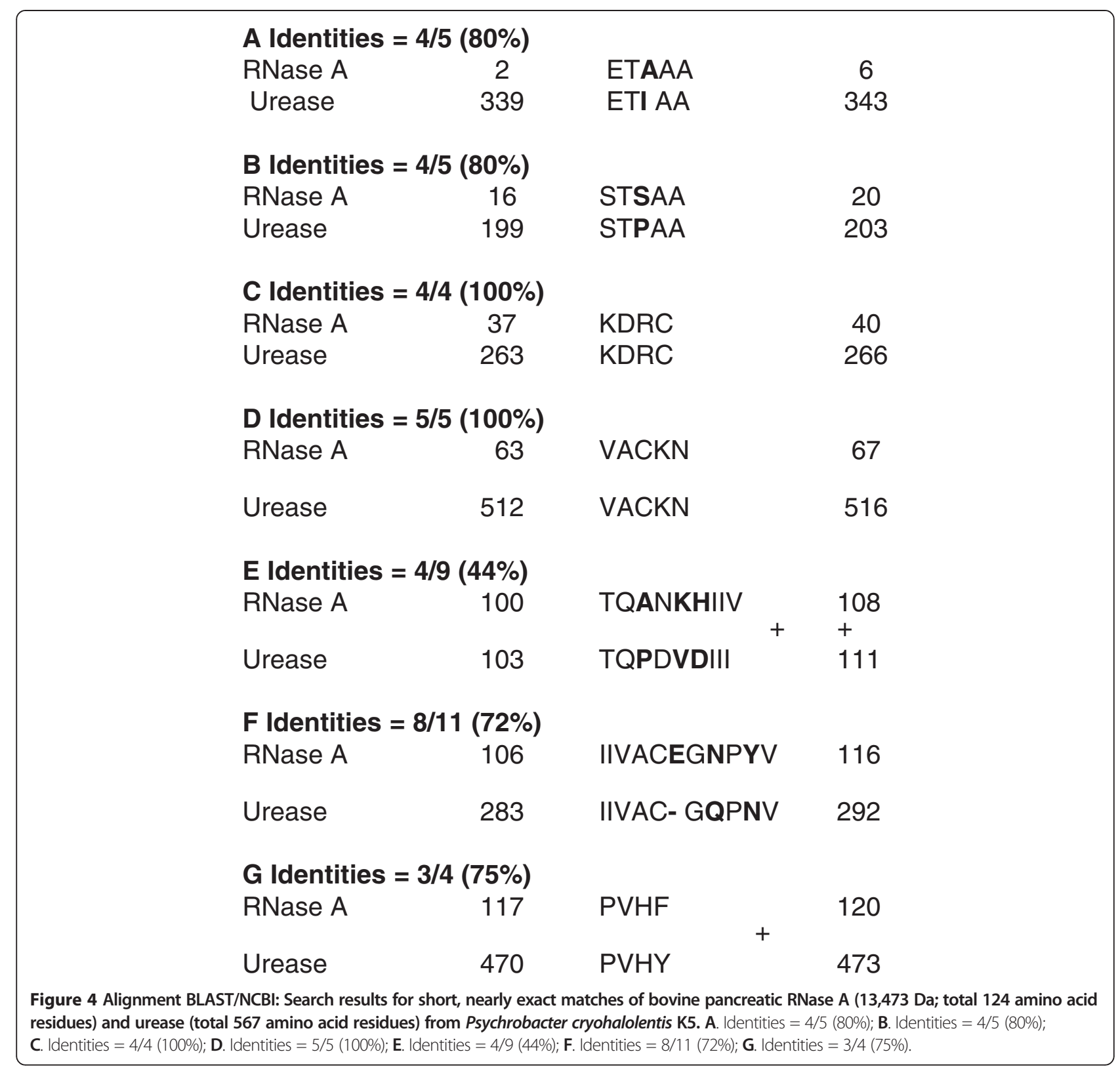

July leaf Ni concentrations of $1-4 \mu \mathrm{gg}^{-1}$ dry weight, which is considered to be within the 'sufficiency' range for $\mathrm{Ni}$ in pecan. The $\mathrm{Ni}^{-}$trees had Ni concentrations $\leq 0.8 \mu \mathrm{gg}^{-1}$ dry weight [33], which is low enough to trigger the appearance of easily visible morphology based symptoms.
Six specimens from each of the two 'Ni status classes' were randomly chosen for study from a population of trees, based on expression of visual symptoms of $\mathrm{Ni}$ deficiency occurring at the time of spring bud break. Spring xylem sap was collected and analyzed from

Table 3 Effect of Ni ions on ureolytic activity of pecan xylem sap and bovine pancreatic RNase A

\begin{tabular}{cccc}
\hline $\begin{array}{c}\text { Nickel (II) Nitrate concentration In } \\
\text { Prepared Solution }(\boldsymbol{\mu} \boldsymbol{M})\end{array}$ & $\begin{array}{c}\text { In reaction system } \\
(\boldsymbol{\mu} \mathbf{M} / \mathbf{m})\end{array}$ & $\begin{array}{c}\text { Relative ureolytic activity of pecan } \\
\text { Xylem Sap RNase A (\%) }\end{array}$ & $\begin{array}{c}\text { Relative ureolytic activity of bovine } \\
\text { Pancreatic RNase A (\%) }\end{array}$ \\
\hline 0 & 0 & 100 & 100 \\
333 & 0.003 & 150 & 143 \\
1,000 & 0.010 & 188 & 174 \\
3,333 & 0.033 & 251 & 238 \\
\hline
\end{tabular}




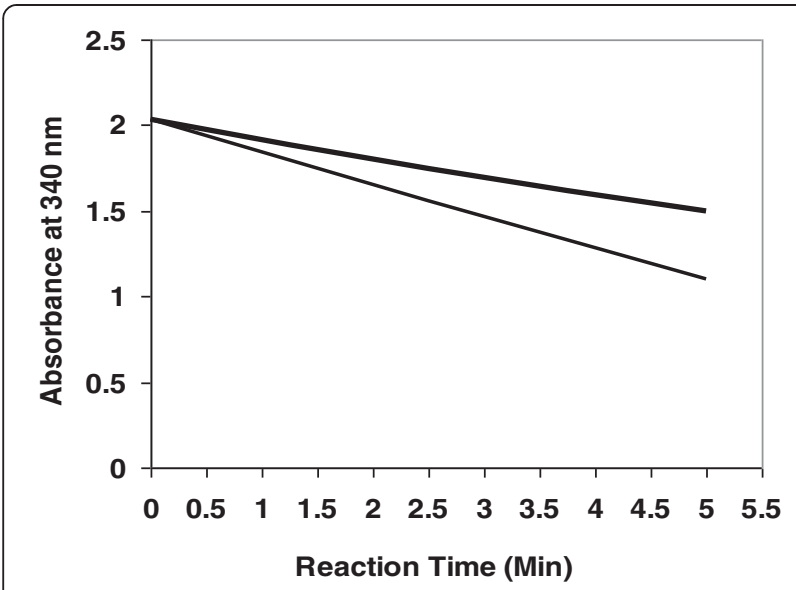

Figure 5 Bovine pancreatic RNase A catalyzing the hydrolysis of urea. Net absorbance at $340 \mathrm{~nm}$ was scanned after adding bovine pancreatic RNase A [6.7 $\mu \mathrm{g}$ protein (upper line) and $20 \mu \mathrm{g}$ protein (lower line)] into the reaction mixture for urease activity assay. Data indicates a positive correlation between the amounts of RNase $A$ added to the reaction mixture and the breakdown of urea. A very similar graph was obtained with pecan sap RNase A catalyzing the hydrolysis of urea.

several trees exhibiting the two classes of Ni nutritional status. Collection was at bud break, with bud break defined as inner bud scale split of $>50 \%$ of primary apical buds. Xylem sap was collected by vacuum extracted from stems severed at the root collar and again just below the apical tip; with the phloem and bark associated with the stem base peeled back to ensure that xylem sap was not contaminated with phloem sap. The base of severed stems was placed under vacuum and the exuding xylem sap dripped into $2 \mathrm{ml}$ collection vials. Total Ni concentration of xylem sap of $\mathrm{Ni}^{-}$and $\mathrm{Ni}^{+}$trees was determined with xylem sap collected as described above, and quantified by ICP-MS [34].

\section{Extraction and purification of xylem sap urease}

The xylem sap samples were diluted in Buffer E [25 mM 2-morpholineethanesulfonic acid (Mes), pH 6.2, $2.5 \mathrm{mM}$ $\mathrm{MnSO}_{4}$, and $2.5 \mathrm{mM} \mathrm{DTT]}$ and centrifuged at 20,000 $\mathrm{g}$ for $1 \mathrm{~h}$ and 30,000 $g$ for $1 \mathrm{~h}$. This supernate was passed through a $0.22 \mu \mathrm{M}$ membrane to remove impurities, and then twice extracted with chilled acetone (90\%) to precipitate proteins. This precipitate was dissolved in Buffer $\mathrm{E}$, with protein purification via ammonium sulfate fractionation, gel filtration chromatography and ion exchange chromatography according to previously reported methods [35]. Proteins were further purified by passing through ammonium sulfate fractionation (50\%), filtering to exclude $\leq 10 \mathrm{kDa}$ molecules (Amicon Centricon YM-10, Millipore Corporation, Bedford, Ma, USA), and finally via gel filtration (Superdex 200 10/ 300 GL column; controlled by ÄKTAbasic -Systems,
Amersham Biosciences, Piscataway, NJ, USA) and ion exchange (Mono Q H/R 5/5 column; controlled by ÄKTAbasic -Systems) chromatography. Buffer E was used as solvents and $\mathrm{NaCl}$ was added into Buffer $\mathrm{E}$ for the salt gradient elution during purification [36]. Fractions with urease activity were pooled, desalted using a small P-10 column, and concentrated by centrifugation for $2 \mathrm{~h}$ at $5,000 \mathrm{~g}$ at $4^{\circ} \mathrm{C}$ with Amicon Centricon YM-10. The smaller molecules were removed because they contain phenolic substances that interfere with enzyme activity. Fresh purified enzyme was subsequently loaded on large $(16 \mathrm{~cm} \times 16 \mathrm{~cm})$ gradient $(8-16 \%)$ sodium dodecyl sulphate -polyacrylamide electrophoresis (SDS-PAGE) gels for purity analysis.

\section{RNase $A$ source and activity}

RNase A from bovine pancreas (90 units/mg protein) came from the USIB Corporation (Cleveland, OH, USA). Its purity was examined with SDS-PAGE (10-20\% gradient gel, $16 \mathrm{~cm} \times 16 \mathrm{~cm}$ in size) while controlling temperature (at $12-15^{\circ} \mathrm{C}$ ) during electrophoresis. Purified protein was denatured in SDS-gel sample buffer and electrophoresed on a SDS- 10 to $20 \%$ polyacrylamide gradient gel. The nuclease activity of RNase A from bovine pancreas was verified by suspending RNA (ribonucleic acid from baker's yeast, Saccharomyces cereviae; Sigma, St. Louis, Mo, USA) in Buffer E [25 mM 2morpholineethanesulfonic acid (Mes), pH 6.2, $2.5 \mathrm{mM}$ $\mathrm{MnSO}_{4}$, and $\left.2.5 \mathrm{mM} \mathrm{DTT}\right)$ [35]. RNase A $(10 \mu \mathrm{L})$ was then added to the RNA suspension and the reaction mixture $(2 \mathrm{mg} / \mathrm{ml})$ incubated at $25^{\circ} \mathrm{C}$ for $1 \mathrm{~h}$ and then centrifuged $\left(5,500_{\mathrm{g}}\right.$ at $\left.4^{\circ} \mathrm{C}\right)$. The mixture was then filtered to exclude $\leq 50 \mathrm{kDa}$ molecules (Amicon Centricon YM-50, Millipore Corporation, Bedford, Ma, USA). The fraction was rinsed with Buffer $E$, centrifuged (at $5,500_{\mathrm{g}}$ at $4^{\circ} \mathrm{C}$ ), and again filtered to exclude $\leq 50 \mathrm{kDa}$ molecules. The $>50 \mathrm{kDa}$ fractionation was suspended in Buffer $\mathrm{E}(2 \mathrm{ml})$ and the reaction monitored based on absorbance at $260 \mathrm{~nm}$. Buffer E served as a blank and untreated RNA $(2 \mathrm{ml})$ served as a positive control.

\section{Assay of urease activity in protein solutions with molecular mass $\geq 10 \mathrm{kD}$}

Urease activity was described by Kaltwasser and Schlegel [36], but with slight modification [37]. The assay is completed as a coupled enzyme with Glu dehydrogenase. All chemical assay reagents were dissolved in $0.1 \mathrm{M}$ potassium phosphate buffer $(\mathrm{pH}$ 7.6). The assay mix was $0.37 \mathrm{ml}$ of $0.1 \mathrm{M}$ potassium phosphate buffer ( $\mathrm{pH} 7.6$ ), $0.1 \mathrm{ml}$ of $1.8 \mathrm{M}$ urea, $0.1 \mathrm{ml}$ of $0.025 \mathrm{M}$ ADP, $0.2 \mathrm{ml}$ of $0.008 \mathrm{M} \mathrm{NADH}, 0.1 \mathrm{ml}$ of $0.025 \mathrm{M} \alpha$-ketoglutarate before adding $0.1 \mathrm{ml}$ of 50 units $/ \mathrm{ml}$ Glu dehydrogenase and $5 \mu \mathrm{L}$ of enzyme solution. The change in $A_{340}$ at $25^{\circ} \mathrm{C}$ 
was recorded at $0.5,1,3$, and 5 min. Urease of jack bean (Canavalia ensiformis; 29.5 units/mg; Sigma, St. Louis, Mo, USA) was used as a reference. A unit is defined as the amount of urease causing oxidation of $1 \mu \mathrm{M}$ of $\mathrm{NADH} / \mathrm{min}$ at $25^{\circ} \mathrm{C}, \mathrm{pH} 7.6$, in a coupled reaction using Glu dehydrogenase. Protein concentration was determined with the Bio-Rad protein assay with bovine serum albumin as standard.

\section{Effect of nickel ions on urease activity of RNase A}

The purified RNase A solution $(10 \mu \mathrm{l})$, either from bovine or pecan sap, was mixed with $10 \mu \mathrm{l}$ of Ni-nitrate solution at different concentrations $(0,333,1,000$, and $3,300 \mu \mathrm{M}$, respectively) in a cuvette to give a final $\mathrm{Ni}$ concentration of $0,0.0033,0.0100$, and $0.0333 \mu \mathrm{M} / \mathrm{ml}$. After $2 \mathrm{~min}, 998 \mu \mathrm{l}$ of chemical substrate solution was added and mixed, with measurement of urease activity determined as described above.

\section{Determination of the $\mathrm{N}$-terminal amino acid sequence}

Purified urease from pecan sap was denatured in SDSgel sample buffer and electrophoresed on an SDS-10 to $20 \%$ polyacrylamide gradient gel and then the protein was transferred to a PVDF membrane. The amino acid sequence of N-terminals was determined by Edman degradation and performed by a Molecular Biology Resource Facility (University of Oklahoma Health Science Center, Oklahoma City, OK, USA).

\section{Abbreviations}

RNase: Ribonuclease; N: Nitrogen; Ni: Nickel; SDS: Sodium dodecyl sulphate: PAGE: Polyacrylamide gel electrophoresis; PVDF: Polyvinylidene fluoride; MES: Morpholineethanesulfonic acid; DTT: Dithiothreitol; BLAST: The Basic Local Alignment Search; NCBI: The National Center for Biotechnology Information; STD: Standard; ADP: Adenine 5'-diphosphate; NADH: Nicotinamide adenine dinucleotide, reduced form; 2D gel: Two dimension gel.

\section{Competing interests}

The authors declare that they have no competing interests.

\section{Authors' contributions}

CB collaborated in the designed the concept, conducted most experiments and contributed to the manuscript. LPL performed some experiments and participated in the interpretation of the results. BWW participated in the design of concept, $\mathrm{Ni}$ analysis, interpretation of results, and writing and editing the manuscript. All authors read and approved the final manuscript.

\section{Acknowledgments}

This study was supported by the United States Department of Agriculture, Agricultural Research Service and by The Introduction of Talent Project of the Environment and Plant Protection Institute, Chinese Academy of Tropical Agricultural Sciences partially supported this study (No. HZS1101).

Received: 10 July 2013 Accepted: 3 December 2013

Published: 9 December 2013

\section{References}

1. Mulrooney SB, Hausinger RP: Nickel uptake and utilization by microorganisms. FEMS Microbiol Rev 2003, 27:239-261.
2. Witte $C P$, Medina-Escobar N: In-gel detection of urease with nitroblue tetrazolium and quantification of the enzyme from different crop plants using the indophenol reaction. Anal Biochem 2001, 290:102-107.

3. Hogan ME, Swift IE, Done J: Urease assay and ammonia urease from leaf tissues. Phytochemistry 1983, 22:663-667.

4. Frankenberger WT, Tabatabai MA: Amidase and urease activities in plants. Plant Soil 1982, 64:153-166.

5. Nielsen FH: Ultratrace elements in nutrition: current knowledge and speculation. J Trace Elements Exper Med 1998, 11:251-274.

6. Mamiya G, Takishima K, Masakuni M, Kayuumi T, Ogawa K: Complete amino acid sequence of jack bean urease. The Protein J 1987, 6:55-59.

7. Todd MJ, Hausinger RP: Purification and characterization of the nickel-containing multicomponent urease from Klebsiella aerogenes. J Biol Chem 1987, 262:5963-5967.

8. Raines RT: Ribonuclease A. Chem Rev 1998, 98:1045-1066.

9. Cuchillo CM, Nogués MV, Raines RT: Bovine pancreatic ribonuclease: fifty years of the first enzymatic reaction mechanism. Biochemistry 2011, 50:7835-7841

10. Beintema JJ: Introduction: the ribonuclease A superfamily. CMLS Cell MOl Life Sci 1998, 54:763-765

11. Beintema JJ, Kleineedam RG: The ribonuclease A superfamily: general discussion. CMLS Cell Mol Life Sci 1998, 54:825-832.

12. Dixon NC, Gazzola C, Blakely RL, Zemer R: Jack bean urease (EC 3.5.1.5) A metalloenzyme: a simple biological role for nickel. J Am Chem Soc 1975, 97:4131-4141.

13. Ciurli S: Electronic structure of the nickel ions in the active site of urease. Chemistry (Easton) 2001, 2001:99-100.

14. Scheraga HA, Wedemeyer WJ, Welker E: Bovine pancreatic ribonuclease A: oxidative and conformational folding studies. Meth Enzymol 2001, 341:189-221.

15. Sheldrake AR, Norhcote DH: Site of phenylalanine ammonialyase activity and synthesis of lignin during xylem differentiation. Nature 1969, 219:1230-1234.

16. Malavolta E, Moraes MF: Nickel - from toxic to essential nutrient. Better Crops 2007, 91:26-27.

17. Beintema JJ: Primary structures of pancreatic ribonucleases from Bovidae, Impala, Thomson's gazelle, nilgai and water buffalo. Biochem Biophys Acta 2009, 621:89-102.

18. Latched SF, Madden TL, Schaffer A, Zhang A, Zhang J, Miller ZW, Lipman DJ: Gapped BLAST and PSI-LAST: a new generation of protein database search programs. Nucleic Acids Res 1997, 25:3389-3402.

19. Balakrishnan R, Ramasubbu N, Varughese Kl, Parthasarathy R: Crystal structures of the copper and nickel complexes of RNase A: metal-induced interprotein interactions and identification of a novel copper binding motif. Proc Natl Acad Sci U S A 1997, 94:9620-9625.

20. Thomson AJ: Proteins containing nickel. Nature 1982, 298:602-603.

21. Walsh CT, Orme-Johnson WH: Nickel enzymes. Biochemistry 1987, 26:4901-4906.

22. Gerendás J, Sattelmacher B: Significance of Ni supply for growth, urease activity and concentrations of urea, amino acids and mineral nutrients of urea-grown plants. Plant Soil 1997, 190:153-162.

23. Wood BW, Reilly CC, Nyczepir AP: Field deficiency of nickel in trees: symptoms and causes. Acta Hort 2006, 721:83-98.

24. Maheshwari R, Dubey RS: Nickel toxicity inhibits ribonuclease and protease activities in rice seedlings: protective effects of proline. Plant Growth Regul 2007, 51:231-243.

25. Maheshwari R, Dubey RS: Inhibition of ribonuclease and protease activities in germinating rice seeds exposed to nickel. Acta Physiol Plant 2008, 30:863-872.

26. Pandey VK, Gopal R: Nickel toxicity effects on growth and metabolism of eggplant. Inter J Vegetable Sci 2010, 16:351-360.

27. Schubert KR, Boland MJ: The ureides. In The Biochemistry of Plants, Volume 16. Edited by Miflin BJ, Lea PJ. San Diego: Academic Press; 1990:197-283.

28. Todd CC, Tipton PA, Blevins DG, Piedras P, Pineda M, Polacco JC: Update on ureide degradation in legumes. J Expt Bot 2006, 57:5-12.

29. Bai C, Reilly CC, Wood BW: Nickel deficiency affects nitrogenous forms and urease activity in spring xylem sap of pecan. J American Soc Hort SC 2007, 132:302-309.

30. Triffin LO: Translocation of nickel in xylem exudates of plants. Plant Physiol 1971, 48:273-277.

31. Cataldo DA, Garland TR, Wildung RE: Nickel in plants: II. Distribution and chemical form in soybean plants. Plant Physiol 1978, 62:566-570. 
32. Cataldo KM, McFadden TR, Garland RE, Wildung RE: Organic constituents and complexation of nickel(II), iron(III), cadmium(II) and plutonium(IV) in soybean xylem exudates. Plant Physiol 1988, 86:734-739.

33. Nyczepir AP, Wood BW, Reilly CC: Association of Meloidogyne partityla with nickel deficiency of mouse-ear of pecan. Hort Sci 2006, 41:402-404.

34. Wood BW, Grauke L: The rare-earth metallome of pecan and other Carya. J Amer Soc Hort Sci 2011, 136:389-398.

35. Kaltwasser $\mathrm{H}$, Schlegel HG: NADH-dependent coupled enzyme assay for urease and other ammonia-producing systems. Anal Biochem 1966, 16:132-138.

36. Bai $C$, Fernandez $E$, Chen R: Purification and stabilization of a monomeric is ocitrate dehydrogenase from Corynebacterium glutamicum. Protein Expr Purif 1999, 15:344-348.

37. Bai C, Reilly CC, Wood BW: Nickel deficiency disrupts metabolism of ureides, amino acids, and organic acids of young pecan foliage. Plant Physiol 2006, 140:433-443.

doi:10.1186/1471-2229-13-207

Cite this article as: Bai et al:: Nickel affects xylem Sap RNase a and converts RNase A to a urease. BMC Plant Biology 2013 13:207.

\section{Submit your next manuscript to BioMed Central and take full advantage of:}

- Convenient online submission

- Thorough peer review

- No space constraints or color figure charges

- Immediate publication on acceptance

- Inclusion in PubMed, CAS, Scopus and Google Scholar

- Research which is freely available for redistribution 